\title{
PRESERVATION OF NORMAL HUMAN PLASMA IN THE LIQUID STATE. IV. STUDIES ON ISOHEMAGGLUTININ TITERS ${ }^{1}$
}

\author{
By EUGENE L. LOZNER 2 AND LLOYD R. NEWHOUSER * \\ (From the Naval Medical Research Institute and the Naval Medical School, \\ National Naval Medical Center, Bethesda, Maryland)
}

(Received for publication November 29, 1943)

The presence of isohemagglutinins in plasma has prompted at least two observers to attribute untoward reactions following the administration of pooled plasma to this factor $(1,2)$. While it is conceivable that in plasma from a single donor, the same hazard may theoretically exist as in blood from a "dangerous universal donor," it is nevertheless a fact, as has been pointed out by Thalhimer (3), that for purposes of bacteriologic control, the preparation of plasma on a large scale invariably involves pooling. It is the purpose of this communication therefore to report isohemagglutinin titrations on 1000 pools of plasma as compared with 100 monovalent controls and to present a preliminary investigation of the clinical significance of the isoagglutinin titers of pooled plasma.

\section{METHODS}

One thousand specimens of pools of plasma, prepared by the Blood Plasma Department of the U. S. Naval Medical School, were analyzed for their titer of isohemagglutinin against " $A$ " and " $B$ " red cell suspensions. The method of plasma preparation has been described previously (4). The method of titration was that in which $0.5 \mathrm{ml}$. of plasma was diluted geometrically with 0.9 per cent sodium chloride in a rack of $10 \times 75 \mathrm{~mm}$. test tubes. To each dilution is added $0.5 \mathrm{ml}$. of a 1 per cent washed red cell suspension from a panel of " $A$ " and " $B$ " individuals. The tubes are allowed to stand without agitation for 2 hours at $37^{\circ} \mathrm{C}$. Following this, each tube is gently agitated and the endpoint is read as the last tube in which macroscopic agglutinates are present. The first tube, i.e., that in which $0.5 \mathrm{ml}$. undiluted plasma has been added to $0.5 \mathrm{ml}$. red cell suspension, is called " $1: 2$ " inasmuch as a 50 per cent dilution of the plasma is present. All titrations were done in duplicate and each time a series of titrations was run,

1 This article has been released for publication by the Division of Publications of the Bureau of Medicine and Surgery of the U.S. Navy. The opinions are those of the writers and are not to be considered as reflecting the policies of the Navy Department.

${ }^{2}$ Lieutenant, Medical Corps, United States Naval Reserve.

Captain, Medical Corps, United States Navy. controls consisting of plasma from a known " $A$ " and a known " $B$ " individual were also run. In all, 100 " $A$ " and 100 " $\mathrm{B}$ " monovalent control titrations were done. The pooled plasma varied with respect to age of preservation in the liquid state and to the number of donors of the pool.

In connection with the statistical study of blood plasma administration presented in the first paper of this series (5), it was possible to compare the distribution of agglutinin titers in those lots of plasma which had been reported as being followed by untoward reactions with a sample of those lots of plasma which had been reported as not followed by reactions. It was also possible to determine the reaction percentage in the administration of those lots of plasma which turned out to have agglutinin titers over "1 : 16."

\section{RESULTS}

The distribution of isohemagglutinin titers in 1000 pools of plasma and 100 monovalent controls and the correlations with the age of plasma and with the number of donors contributing to the pools are presented in the accompanying tables (Tables I and II).

It will be observed that pooling alone reduces the percentage of the group with titers of "1 $: 16$ " and over from 72 per cent in the controls to 7.7 per cent in the pools, with respect to anti-A agglutinin, and from 78 per cent in the controls to 15.2 per cent in the pools, with respect to anti-B agglutinin.

The difference between pools with only 5 to 8 donors contributing to them and those with 9 to 12 donors is striking. Whereas the former group had percentages of titers of " $1: 16$ " and over, of 8.1 per cent and 15.7 per cent of anti-A and anti-B agglutinin, respectively, the latter had percentages of 1.5 per cent and 8.7 per cent.

It is also evident that aging the plasma in the liquid state over 4 months also decreases considerably the percentage of the group with titers of " $1: 16$ " and over. In 145 pools over 4 months old, none had a titer of " $1: 16$ " or over of anti-A agglutinin and 7 had titers of " $1: 16$ " to "1 : 64," but none over "1 : 64 ," of anti-B 
agglutinin. Between the group under 1 month old and the group 1 to 4 months old, however, no significant difference could be elicited.

The clinical significance of the agglutinin titers in pooled plasma was investigated by means of two approaches as described above. Thus far, 15 administrations of pools with titers known to be over "1:16" have been performed without untoward reaction. In addition, no correlation could be elicited between titer and untoward reactions as tabulated in the statistical analysis of the first paper of this series (5).

\section{DISCUSSION}

The data presented here tend to discredit the reports $(1,2)$ that untoward reactions may be due to the titer of agglutinins present in pooled plasma. The reaction reported by Polayes and Squillace (1) was ascribed by them to the presence of a " $1: 8$ " titer of agglutinins. In the thousand pools studied here, $\mathbf{1 7 . 7}$ per cent had a titer of " $1: 8$ " or over of anti-A agglutinin and 28.6 per cent of anti-B agglutinin. Yet there was no increase in untoward reaction rate in this group. If the premise of Polayes and Squillace were correct, practically no type " $O$ " blood could be transfused into a heterologous patient. Thousands of such transfusions have been and are being performed with no greater than the usual percentage of untoward reactions. A titer of " $1: 8$ " would be innocuous on the basis of dilution alone in the recipient's bloodstream and there appear to be factors in addition to dilution which enable patients to tolerate incompatible agglutinins.

The reaction reported by Downs (2) was typically urticarial, quickly responding to adrenalin. Nevertheless, he ascribed it to an incompatibility between the plasma and the patient's blood, although no test for such incompatibility was performed, and he advocated preliminary crossmatching before every administration of plasma. Our data indicate that such cross-matching would show the presence of small concentrations of agglutinins about 50 per cent of the time. Such concentrations of agglutinins cannot be

TABLE I

Analysis of anti- $A$ isoagglutinin titration on 1000 pools of plasma

\begin{tabular}{|c|c|c|c|c|c|c|c|c|c|c|c|c|}
\hline Groups & & $\mathbf{0}$ & $1: 2$ & $1: 4$ & $1: 8$ & $1: 16$ & $1: 32$ & $1: 64$ & $1: 128$ & $1: 256$ & $1: 512$ & Total \\
\hline \multirow{2}{*}{$\begin{array}{l}\text { Monovalent } \\
\text { controls }\end{array}$} & Number & 0 & 0 & 5 & 23 & 25 & 21 & 17 & 4 & 4 & 1 & 100 \\
\hline & Per cent & 0 & 0 & 5 & 23 & 25 & 21 & $\begin{array}{l}17 \\
72 \text { pe }\end{array}$ & $\begin{array}{c}4 \\
\text { cent }\end{array}$ & 4 & 1 & $\begin{array}{l}100 \\
\text { per cent }\end{array}$ \\
\hline \multirow{2}{*}{$\begin{array}{l}\text { Total } \\
\text { pools }\end{array}$} & Number & 551 & 144 & 128 & 100 & 48 & 14 & 12 & 3 & 0 & 0 & 1000 \\
\hline & Per cent & 55.1 & 14.4 & 12.8 & 10.0 & 4.8 & 1.4 & 1.2 & 0.3 & 0 & 0 & $\begin{array}{c}100 \\
\text { per cent }\end{array}$ \\
\hline \multirow{2}{*}{$\begin{array}{c}\text { Pools with } 5 \text { to } 8 \\
\text { donors }\end{array}$} & Number & 510 & 133 & 120 & 92 & 47 & 14 & 12 & 3 & 0 & 0 & 931 \\
\hline & Per cent & 54.8 & 14.3 & 12.9 & 9.9 & 5.0 & 1.5 & 1.3 & 0.3 & 0 & 0 & $\begin{array}{c}100 \\
\text { per cent }\end{array}$ \\
\hline \multirow{2}{*}{$\begin{array}{c}\text { Pools with } 9 \text { to } 12 \\
\text { donors }\end{array}$} & Number & 41 & 11 & 8 & 8 & 1 & 0 & 0 & 0 & 0 & 0 & 69 \\
\hline & Per cent & 59.4 & 15.9 & 11.6 & 11.6 & 1.5 & 0 & 0 & 0 & 0 & 0 & $\begin{array}{c}100 \\
\text { per cent }\end{array}$ \\
\hline \multirow{3}{*}{$\begin{array}{l}\text { Pools under } \\
1 \text { month old }\end{array}$} & Number & 284 & 93 & 91 & 70 & 29 & 7 & 11 & 0 & 0 & 0 & 585 \\
\hline & Per cent & 48.5 & 15.9 & 15.6 & 12 & 5.0 & 1.1 & 1.9 & 0 & 0 & 0 & \multirow{2}{*}{$\begin{array}{l}100 \\
\text { per cent }\end{array}$} \\
\hline & & & & & & & & & & & & \\
\hline \multirow{2}{*}{$\begin{array}{l}\text { Pools } 1 \text { to } 4 \text { months } \\
\text { old (Liquid) }\end{array}$} & Number & 156 & 34 & 29 & 21 & 19 & 7 & 1 & 3 & 0 & 0 & 270 \\
\hline & Per cent & 57.8 & 12.6 & 10.7 & 7.8 & 7.0 & 2.6 & 0.4 & 1.1 & 0 & 0 & $\begin{array}{l}100 \\
\text { per cent }\end{array}$ \\
\hline \multirow{3}{*}{$\begin{array}{l}\text { Pools over } 4 \text { months } \\
\text { old (Liquid) }\end{array}$} & Numhar & 111 & 17 & 8 & 0 & 0 & 0 & 0 & 0 & 0 & 0 & 115 \\
\hline & & & & & & & & & & & & \multirow{2}{*}{$\begin{array}{c}100 \\
\text { per cent }\end{array}$} \\
\hline & Per cent & 76.6 & 11.7 & 5.5 & 6.2 & 0 & 0 & $\begin{array}{c}0 \\
0 \\
\text { per }\end{array}$ & $\begin{array}{c}0 \\
\text { cent }\end{array}$ & 0 & 0 & \\
\hline
\end{tabular}


TABLE II

Analysis of anti-B agglutinin titrations on 1000 pools of plasma

\begin{tabular}{|c|c|c|c|c|c|c|c|c|c|c|c|c|}
\hline Groups & & $\mathbf{0}$ & $1: 2$ & $1: 4$ & $1: 8$ & $1: 16$ & $1: 32$ & $1: 64$ & $1: 128$ & $1: 256$ & $1: 512$ & Total \\
\hline \multirow{2}{*}{$\begin{array}{l}\text { Monovalent } \\
\text { controls }\end{array}$} & Number & 0 & 0 & 4 & 18 & 32 & 25 & 10 & 5 & 4 & 2 & 100 \\
\hline & Per cent & 0 & 0 & 4 & 18 & 32 & 25 & 10 & 5 & 4 & 2 & $\begin{array}{c}100 \\
\text { per cent }\end{array}$ \\
\hline \multirow{2}{*}{$\begin{array}{l}\text { Total } \\
\text { pools }\end{array}$} & Number & 329 & 187 & 198 & 134 & 92 & 42 & 13 & 2 & 2 & 1 & 1000 \\
\hline & Per cent & 32.9 & 18.7 & 19.8 & 13.4 & 9.2 & 4.2 & 1.3 & 0.2 & 0.2 & 0.1 & $\begin{array}{c}100 \\
\text { per cent }\end{array}$ \\
\hline \multirow{2}{*}{$\begin{array}{c}\text { Pools with } 5 \text { to } 8 \\
\text { donors }\end{array}$} & Number & 299 & 171 & 185 & 130 & 90 & 40 & 11 & 2 & 2 & 1 & 931 \\
\hline & Per cent & 32.1 & 18.4 & 19.9 & 14 & 9.7 & 4.3 & $\begin{array}{r}1.2 \\
15.7\end{array}$ & $\begin{array}{l}0.2 \\
\text { cent }\end{array}$ & 0.2 & 0.1 & $\begin{array}{c}100 \\
\text { per cent }\end{array}$ \\
\hline \multirow{2}{*}{$\begin{array}{l}\text { Pools with } 9 \text { to } 12 \\
\text { donors }\end{array}$} & Number & 30 & 16 & 13 & 4 & 2 & 2 & 2 & 0 & 0 & 0 & 69 \\
\hline & Per cent & 43.5 & 23.2 & 18.8 & 5.8 & 2.9 & 2.9 & 2.9 & 0 & 0 & 0 & $\begin{array}{c}100 \\
\text { per cent }\end{array}$ \\
\hline \multirow{2}{*}{$\begin{array}{l}\text { Pools under } \\
1 \text { month old }\end{array}$} & Number & 148 & 113 & 130 & 93 & 59 & 27 & 10 & 2 & 2 & 1 & 585 \\
\hline & Per cent & 25.3 & 19.3 & 22.2 & 15.9 & 10.2 & 4.6 & 1.7 & 0.3 & 0.3 & 0.2 & $\begin{array}{c}100 \\
\text { per cent }\end{array}$ \\
\hline \multirow{3}{*}{$\begin{array}{l}\text { Pools } 1 \text { to } 4 \text { months } \\
\text { old (Liquid) }\end{array}$} & Number & 92 & 52 & 50 & 32 & 28 & 14 & 2 & 0 & 0 & 0 & 270 \\
\hline & Per cent & 34.1 & 19.3 & 18.5 & 11.8 & 10.4 & 5.2 & 0.7 & 0 & 0 & 0 & \multirow{2}{*}{$\begin{array}{l}100 \\
\text { per cent }\end{array}$} \\
\hline & & & & & & & & & & & & \\
\hline \multirow{2}{*}{$\begin{array}{c}\text { Pools over } 4 \text { months } \\
\text { old (Liquid) }\end{array}$} & Number & 89 & 22 & 18 & 9 & 5 & 1 & 1 & 0 & 0 & 0 & 145 \\
\hline & Per cent & 61.4 & 15.2 & 12.4 & 6.2 & 3.4 & 0.7 & 0.7 & 0 & 0 & 0 & $\begin{array}{c}100 \\
\text { per cent }\end{array}$ \\
\hline
\end{tabular}

demonstrated to be harmful and it may be concluded therefore that preliminary crossmatching of pooled plasma does not appear to be justified experimentally.

\section{SUMMARY AND CONCLUSIONS}

1. An analysis of isohemagglutinin titrations on 1000 pools of plasma and 100 monovalent controls is presented.

2. Pooling the plasma reduced the percentage with titers of " $1: 16$ " and over, of anti-A isoagglutinin from 72 per cent in the controls to 7.7 per cent in the pools, and of anti-B isoagglutinin from 78 per cent in the controls to 15.2 per cent.

3. Pools with 9 to 12 donors have a lower percentage of titers of isoagglutinins of " $1: 16$ " and over than pools with 5 to 8 donors.

4. Pools over 4 months old have a much lower percentage of titers over " $1: 16$ " than pools under 4 months old.

5. To date, 15 administrations of plasma with titers over "1 : 16" have been performed without untoward reaction. There was also no significant difference in titers of isoagglutinin in lots of plasma reported as being followed by untoward reactions, compared with lots of plasma which were reported as not followed by reactions.

6. It may be concluded that thus far there is no evidence for any harmful effect from the titer of isohemagglutinins present in pooled plasma, and, consequently, no justification for preliminary cross-matching of such plasma prior to administration.

\section{BIBLIOGRAPHY}

1. Polayes, S. H., and Squillace, J. A., Near fatal reaction to transfusion with dried human plasma solution. J.A.M.A., 1942, 118, 1050.

2. Downs, T. McK., A reaction to dried pooled human plasma. U. S. Nav. M. Bull., 1943, 41, 189.

3. Thalhimer, W., Intravenous injection of pooled normal plasma or serum: Is it dangerous? J.A.M.A., 1942, $120,1263$.

4. Newhouser, L. R., and Kendrick, D. B., Human Plasma Manual. U. S. Naval Medical School, Washington, D. C., 1941.

5. Lozner, E. L., and Newhouser, L. R., Preservation of normal human plasma in the liquid state. I. A statistical study of 1751 administrations. J. Clin. Invest., 1944, 23, 343. 